\title{
Membaca Media Daring, Mengikuti Media Sosial: Di Mana Etika?
}

\author{
Lukas S. Ispandriarno \\ Program Studi Ilmu Komunikasi, Universitas Atma Jaya Yogyakarta
}

\section{ABSTRAK}

Berita di media dalam jaringan (online) memanfaatkan sensasi, misalnya dalam berita kematian mahasiswi. Penggunaan bahasa berupa diksi yang "wah," penyebutan identitas lengkap, tidak mengindahkan kode etik jurnalistik serta tidak menunjukkan empati pada korban. Dalam isu yang sama, kematian tidak wajar seorang mahasiswi, pesan atau gambar di media sosial juga cenderung sensasional. Ada unsur pornografi atau perendahan martabat perempuan dalam bermedia sosial memanfaatkan WhatsApp. Etika jurnalistik seharusnya memasukkan perspektifjender.

Kata kunci: media daring, media sosial, sensasionalisme, pornografi, etika.

Berita di media online (daring, dalam jaringan) hadir lebih cepat, tampil lebih pendek ketimbang di media cetak. Narasumber lebih sedikit atau tunggal, judul dibuat heboh, termasuk bila mengabarkan peristiwa politik, bencana, kejahatan, kematian. Pendeknya, judul dibikin wah, misalnya diawali dengan kata "Sungguh Tragis!..." Judul-judulnya mirip dengan judul-judul di media kuning, bombastis, sensasional. Perhatikan judul berikut: "Mahasiswi Tewas Melahirkan di Kamar Kos, Polisi Buru Teman Dekat" (jpnn.com, 1 Mei 2015). Judul berita seperti ini tentu menggugah perasaan (sense) sekaligus juga mengundang pertanyaan pembaca.

Dari sisi bahasa, judul itu ganjil. Bagaimana mungkin, "mahasiswi (yang telah) tewas (bisa) melahirkan"? Mustahil bukan? Barangkali yang dimaksudkan adalah "mahasiswi tewas (karena) melahirkan." Kata tewas juga tidak tepat sebab artinya "mati dalam perang atau bencana" (Poerwadarminta, 1985, h.1066). Mahasiswi tersebut meninggal mungkin karena kehabisan darah saat persalinan tanpa bantuan dokter atau petugas kesehatan. Bila si jurnalis paham makna kata tewas, inikah yang dia maksudkan "mahasiswi tewas karena bergulat (berperang) melawan maut, melahirkan tanpa bantuan siapa pun." Begitukah? Menelusuri tubuh berita, tidak ditemukan kata "buru atau memburu". Dalam tubuh berita disebutkan polisi mencari laki-laki yang kemungkinan pacar mahasiswi untuk diminta pertanggungjawaban. Selengkapnya:

\footnotetext{
"Saat melakukan penyelidikan di kamar kos korban, polisi menemukan petunjuk mengenai sosok pria yang diduga menjadi teman dekat cewek Lampung itu.
} 
Pria itu berinisial Gw. "Kami masih mencari teman dekat korban. Dia tinggal di Jakarta," terang Luthfi (Kompol Luthfi, Kapolsek Depok Barat, jpnn.com, 1 Mei 2015).

Menurut Kamus Umum Bahasa Indonesi, kata "buru" atau "memburu" berarti 1.mengejar atau menyusul (hendak menangkap dsb); 2.mencari (menangkap) binatang di hutan dsb (Poerwardarminta, 1985, h.170). Tentu pilihan kata "buru" dalam lebih wah, terkesan seram, menegangkan ketimbang "cari" atau "mencari.

Sirikit Syah (2011, h.25) menyebut persoalan ini sebagai "judul bermasalah" yang menyangkut bahasa yakni diksi, pilihan kata, semantik dan akurasi informasi. Judul yang tidak menggambarkan isi berita dapat dianggap bohong, melanggar Pasal 4 Kode Etik Jurnalistik Indonesia (KEJI).

Judul berikut: "Mahasiswi UPN Jogja Meninggal Saat Melahirkan di Kost.," tidak bombastis tapi tergolong sensasional karena menyebut nama kampus tempat belajar mahasiswi. Penyebutan nama kampus tentu mengundang rasa ingin tahu pembaca. Apalagi, di dalam tubuh berita disebutkan nama Program Studi selain alamat kos, asal daerah, dan nama lengkapnya. Jurnalis seolah ingin mengabarkan dengan terang benderang, siapa gerangan mahasiswi yang meninggal secara tidak wajar ini. Beberapa media daring tidak hanya menampilkan foto lokasi kejadian, namun juga foto diri mahasiswi tersebut. Bisa dibayangkan bagaimana perasaan orang tua, sanak keluarga, handai tolan dan masyarakat di tempat asalnya serta segenap civitas academika kampus. Sungguh, jurnalis tidak memiliki bela rasa, empati, bukan sekadar simpati. Pasal 5 KEJI memang "hanya" menuliskan:"Wartawan Indonesia tidak menyebutkan dan menyiarkan identitas korban kejahatan susila dan tidak menyebut identitas anak yang menjadi pelaku kejahatan." Artinya, berita ini tidak termasuk dalam ketentuan pasal 5 , namun untuk apa jurnalis dan media menuliskan semua identitas mahasiswi?

Itulah kecenderungan berita di media daring yang jumlahnya makin banyak. Dari pelacakan di mesin pencari Google dengan mengetikkan kata kunci "mahasiswi meninggal di tempat kos" diperoleh lebih dari 200 berita atau pesan. Judulnya serupa, seperti contoh dalam table berikut:

Tabel 1. Judul Berita dan Nama Media

\begin{tabular}{|l|l|}
\hline Judul & Nama Media \\
\hline $\begin{array}{l}\text { Inikah Akun Facebook Mahasiswi yang } \\
\text { Tewas di Kamar Kos ... }\end{array}$ & jogja.tribunnews.com \\
\hline $\begin{array}{l}\text { Mahasiswi Tewas Usai Melahirkan Sempat } \\
\text { Bayar Uang Kos ... }\end{array}$ & jogja.tribunnews.com \\
\hline $\begin{array}{l}\text { Sungguh Tragis! Mahasiswi Ditemukan } \\
\text { Tewas Membusuk ... }\end{array}$ & jogja.tribunnews.com \\
\hline $\begin{array}{l}\text { Mahasiswi UPN Jogja Meninggal Saat } \\
\text { Melahirkan di Kost ... }\end{array}$ & eveline.co.id \\
\hline $\begin{array}{l}\text { Mahasiswi Tewas Melahirkan di Kamar Kos, } \\
\text { Polisi Buru .. }\end{array}$ & www.jpnn.com \\
\hline $\begin{array}{l}\text { Melahirkan di Kos Tanpa Bantuan, } \\
\text { Mahasiswi Meninggal ... }\end{array}$ & www.jpnn.com \\
\hline Melahirkan di Kos, Mahasiswi UPN Tewas & www.radarjogja.co.id \\
\hline
\end{tabular}




\begin{tabular}{|l|l|}
\hline Judul & Nama Media \\
\hline $\begin{array}{l}\text { Berita Terkini Mahasiswa UPN Yogyakarta } \\
\text { Tewas Di Kamar ... }\end{array}$ & www.youtube.com \\
\hline $\begin{array}{l}\text { Mahasiswi Yogyakarta Tewas saat } \\
\text { Melahirkan Sendiri ... }\end{array}$ & news.okezone.com \\
\hline
\end{tabular}

Sensasionalism (kata benda) memiliki tiga arti: 1.subject matter, language, or style producing or designed to produce startling or thrilling impressions or to excite and please vulgar taste. Bahasa yang dirancang untuk menghasilkan kesan menggetarkan atau mengejutkan dan menghasilkan rasa vulgar, bagi banyak orang.2.Penggunaan dari atau kepentingan, bahasa, gaya; tabloid murahan bersandar pada sensasionalisme untuk meningkatkan tiras. 3. Filsafat, berupa doktrin bahwa kebaikan ditentukan hanya oleh kepuasan perasaan, atau doktrin bahwa semua ide ditarik dari dan secara esensial diturunkan ke dalam sensasi-sensasi. (dictionary.reference.com). Dalam contoh di atas, misalnya penggunaan kata "tewas" daripada "meninggal" atau kata "buru" ketimbang "cari" serta penyebutan nama kámpus.

Sensasionalisme berhubungan dẹngan kesalahan informasi karena kètidakakuratan. Keprihatinan bahwa informasi adalah salah dan ketika khalayak mengonsumsinya karena gagal memeriksa keakuratan disuarakan oleh Taryn Vis (thefalcononline.com, I4 Mei 2014). Dalam artikel berjudul "Media too focused on sensationalism" ia mengatakan, teknologi dan media sosial telah memungkinkan informasi tidak akurat tersebar dengan cepat. Akibatnya, terbentuk opini yang semakin tidak akurat. Facebook telah menjadi arena peledakan berita palsu, video dan blog. Tìdak semuanya dirancang untuk mengelabuhi, tetapi banyak cerita dan tempelan (post) ditulis tanpa penelitian dan laporan memadai yang dibutuhkan untuk membentuk opini yang benar.
Masalahnya bukan terletak hanya pada informasi salah itu sendiri melainkan pada pengaturan akses informasi. Akurasi dan kesegeraan telah ditempatkan lebih rendah dalam hirarki kepentingan, di bawah penyebaran berita paling anyar dan paling ganas. Bila pacuan ini untuk dilihat, disukai (likes) atau dipilih (votes), ketelitian tidak lagi menjadi prioritas utama.

Kehadiran telepon pintar (smartphone) dengan berbagai aplikasi yang memungkinkan pengguna bertukar pesan seakan mengalahkan media massa tradisional maupun media baru (daring). Orang boleh jadi tak butuh menonton televisi, mendengarkan radio, bahkan mengakses internet untuk mendapatkan informasi. Beragam pesan, termasuk desas-desus tiba atau masuk di telepon genggam pemilik, tanpa diundang. Itukah jurnalisme kontemporer? Di sisi lain, penggunaan teknologi baru dalam pengumpulan dan pelaporan berita telah membuka pilihan etika dan hukum yang menantang jurnalis (Kolodszy, 2013).

Kabar "panas" mahasiswi yang meninggal karena melahirkan tanpa bantuan merupakan salah satu isu yang disukai media tradisional (televisi) dan dikabarkan berulang-ulang dengan tajuk "infotainment." Ini adalah berita besar, headline, dengan gambar seronok $\mathrm{di}$ media kuning, namun juga beranak pinak di media daring. Menyebar pula dengan cepat di media sosial, misalnya di Facebook dan WhatsApp. Di WA keseronokan menjadi-jadi, misalnya disebarluaskan foto tubuh dan posisi mahasiswi bersama orok yang telah meninggal dalam kondisi mengerikan 
dengan darah di sekitarnya. Lalu, di mana etika bermedia?

Tanggal 3 Februari 2012 Dewan Pers menandatangani Pedoman Media Siber. Ini adalah segala bentuk media yang menggunakan wahana internet dan melaksanakan kegiatan jurnalistik, serta memenuhi persyaratan Undang-Undang Pers dan Standar Perusahaan Pers yang ditetapkan Dewan Pers. Dalam pengantarnya dikatakan keberadaan media siber merupakan bagian dari kemerdekaan berpendapat, kemerdekaan berekspresi, dan kemerdekaan pers sebagai hak asasi manusia yang dilindungi Pancasila, UUD 1945, dan Deklarasi Universal HAM PBB. Media ini memiliki karakter khusus yang memerlukan pedoman dan pengelelolaan profesional, memenuhi fungsi, hak dan kewajiban seperti dimanatkan UU Nomor 40 Tahun 1999 tentang Pers dan Kode Etik Jurnalistik. Media siber sepakat bahwa publikasikanya :1. Tidak memuat isi bohong, fitnah, sadis dan cabul; 2. Tidak memuat isi yang mengandung prasangka dan kebencian terkait dengan suku, agama, ras, dan antargolongan (SARA), serta menganjurkan tindakan kekerasan; 3. Tidak memuat isi diskriminatif atas dasar perbedaan jenis kelamin dan bahasa, serta tidak merendahkan martabat orang lemah, miskin, sakit, cacat jiwa, atau cacat jasmani.

Menyimak uraian di atas, setidaknya pedoman ini telah menyebut ketentuan "tidak memuat isi bohong, fitnah, sadis dan cabul." Larangan "bohong" seharusnya dapat mencegah media daring dan media sosial menulis dan menyebarkan berita sensasional, berlebih-lebihan. Namun justru berita sensasional menjadi mode yang tidak ada maksud lain kecuali menaikkan jumlah pengakses. Bagi pengguna media sosial, FB atau WA, penyebaran gambar atau foto sensasional bisa dilatarbelakangi oleh sejumlah alasan. Pertama, sebagai sebuah kegemaran baru untuk dengan segera meneruskan kiriman atau pesan apapun ke teman satu kelompok. Kedua, meneruskan kiriman atau pesan yang dianggap "menarik" atau "wah" agar dianggap "hebat" atau "kaya informasi." Pengalaman sebagai anggota dari beberapa kelompok WA, di sela-sela berbagai nasihat dan kata-kata mutiara, ada kecenderungan anggota laki-laki mengirimkan gambar perempuan dengan tampilan seronok, seksi, bahkan porno. Di sini unsur sensasional sudah bertambah dengan unsur pornografi. Haryatmoko (2007, h.94-95) mengingatkan, pornografi harus ditolak dengan sejumlah argumen. Pertama, perlindungan terhadap orang muda atau anak-anak; kedua, mencegah perendahan martabat perempuan; ketiga, mencegah sifat subersif yang cenderung menghancurkan tatanan nilai seksual keluarga dan masyarakat.

FB atau WA dimiliki banyak anak muda, bahkan anak-anak. Keduanya merupakan media sosial populer di Indonesia. Oleh karenanya pornografi di FB dan WA atau di internet, dengan sangat mudah dilihat khalayak khususnya anak muda. Warga negara Indonesia disebut termasuk penggemar situs pornografi. Menonton gambar atau film porno jelas akan melihat adegan di mana perempuan direndahkan, dijadikan objek. Bila berupa gambar atau film adegan seks, maka akan menimbulkan persepsi yang salah atau rendah terhadap nilai seksual perkawinan. Kesakralan nilai perkawinan merosot jauh karena persetubuhan hanyalah tontonan gratis. Anak muda dan anak-anak dengan sifat menirunya dapat terdorong melakukannya.

Kecenderungan media mendiskreditkan perempuan bagaikan sebuah perjalanan tanpa akhir. Itu adalah sesuatu yang harus diperjuangkan. Sebab keadilan, kesetaraan dan tindakan anti diskriminasi itu tidak akan diberikan secara cuma-cuma (Hartiningsih, 2003). 
Kalangan media, termasuk kalangan pendidikan komunikasi ditantang untuk ikut andil dalam perjuangan tiada akhir ini.

Berbeda dengan media daring yang merupakan bagian dari media arus utama (mainstream), media sosial digunakan oleh khalayak awam yang tidak memiliki latarbelakang jurnalistik. Oleh karena itu, pemahaman etika media diduga jauh lebih rendah ketimbang jurnalis. Pengalaman mengikuti sejumlah kelompok WA membuktikan bahwa dalam kelompok atau komunitas terdidik sekalipun, kecenderungan mengirim gambar berbau porno atau pesan yang merendahkan perempuan dilakukan oleh laki-laki kẹtimbang perempuan.

Lima prinsip etik yang dikemukakan Ed Lamberth terdiri dari, sạtu, kebenaran yang akan melindungi kètidakbiasan, ketelitian dan kompeten. Dua, adil berarti jujur, memperlakukan dẹgan perhatian tinggi isu-isu emosional.
Tiga, bebas, yang melindungi otonomi reporter dari sumber pemerintah dan lembaga lain seperti pengiklan dan pengusaha untuk "memanfaatkan"nya. Empat, manusiawi, melibatkan bantuan pada orang lain dan lima, menjadi penjaga yang bertanggungjawab (Moore and Murray, 2012, h.112-113).

Popularitas media daring dan media sosial menuntut pemahaman dan praktik etika jurnalis serta khalayak. Tanpa pemahaman tersebut media hanya menjadi produsen pesan-pesan banal, remeh temeh, tidak mendidik. Selain membantu menguatkan jaringan sosial, kemudahan memiliki dan menggunakan media sosial dapat menguatkan kecenderungan merendahkan martabat perempuan dengan penyebaran foto dan pesan berbau pornografi. Mengikuti Hartiningsih (2003, 91), kode etik -jurnalistik harus memasukkan perspektif jender. Hukum dan pilihan etika menantang jurnalis dan masyarakat.

\section{Daftar Pustaka:}

Haryatmoko. (2007). Etika Komunikasi Manipulasi Media, Kekerasan, dan Pornografi. Yogyakarta: Kanisius.

Hartiningsih, M. (2003). Jurnal Perempuan 28, 86-93.

Kolodszy, J. (2013). Practicing Convergence Journalism. An Introduction to Cross-Media Storytelling. New York and

London. Routledge.

Moore, R. L and Murray, M.D. (2012). Media Law and Ethics. New York and London: Routledge.
Poerwadarminta (1985). Kamus Umum Bahasa Indonesia. Jakarta: PN Balai Pustaka.

Syah, S. (2011). Rambu Rambu Jurnalistik Dari Undang-undang hingga Hati Nurani. Yogyakarta: Pustaka Pelajar.

http://dictionary.reference.com/browse/s ensationalism

Vis, Taryn. (2014). Media too focused on sensationalism.

efalcononline.com/2014/05/mediatoo-focused-on-sensationalism/ 
Jurnal komunikasi, Volume 10, Nomor 1, Oktober 2015 